\author{
Jung'ın Gölge Arketipi ve Marina Carr'ın Kadın ve Korkuluk Oyunundaki İzleri \\ Cüneyt Özata, Department of Foreign Languages, Ordu University
}

Jung's Shadow Archetype and Its Traces in Marina Carr's Woman and Scarecrow

\begin{abstract}
Being a country that constantly provides well-established writers to the world literature and draws attention as a kind of education country in the eyes of great writers, Ireland embodies a magnificent literary tradition and accumulation from the past to the present. Marina Carr, one of the female playwrights of the contemporary Irish theater of the twentieth century and a contrbuiton of which Ireland to the world literature, stands out among the most important female writers. The main action of Carr's plays is to reflect the psychological dilemmas of individuals who live within the borders of the country and are shaped with Irish culture. In this psychological framework, Carr, who aims to show the introversion of people with depression, often appears as an important playwright, both by rewriting myths and addressing issues that are not familiar to Irish society in her plays. Although, unlike her other plays, she did not use the strategy of rewriting myths in Woman and Scarecrow, she succeeds in giving the play a gothic atmosphere with the Scarecrow character and creates new characters suitable for her own writing style. The play Woman and Scarecrow focuses on Carr's theme of death and makes the audience feel that moment of death and the fear of death that the individual will experience upon realization that life has no meaning when faced with the reality of death. Carr aims to reflect the reality of death to the audience through a shadow character. The moment of death of an old woman who tries to come to terms with her past on her deathbed and takes her pain out of herself is an attempt by Carr to symbolize the reality of death with the characters of Woman and Scarecrow in the play. This study deals with the shadow archetype that Carl Gustav Jung handles in the context of personality theory, forming the dark side of the personality produced by the images in our subconscious, with Scarecrow character created by Carr.
\end{abstract}

Keywords Archetypes, shadow, Jung, doppelgänger, Woman and Scarecrow.

Academical disciplines/fields: Literature, performing arts, psychology.
Özet

Dünya edebiyatına sürekli köklü yazarlar kazandıran, büyük yazarların gözünde bir tür eğitim ülkesi olarak da dikkat çeken bir ülke olan İrlanda, geçmişten günümüze kadar uzanan süreçte görkemli bir edebiyat geleneğini ve birikimini bünyesinde barındıran bir ülke konumundadır. İrlandanın dünya edebiyatına sunduğu yirminci yüzyıl çağdaş İrlanda tiyatrosunun kadın oyun yazarlarından biri olan Marina Carr İrlanda'nın son dönem yetiştirdiği önemli kadın yazarları arasında göze çarpar. Carr oyunlarının temel eylemi ülke sınırları içerisinde yaşayan ve İrlanda kültürü ile yoğrulmuş bireylerin psikolojik açmazlarını yansıtmaktır. $\mathrm{Bu}$ psikolojik çerçevede depresyondaki insanların içe dönük sıkıntılarını göstermeyi amaçlamış olan Carr, genellikle oyunlarında gerek mitleri tekrar yazmasıyla gerekse İrlanda toplumunun alıșık olmadığı konuları ele almasıyla öne çıkan önemli bir oyun yazarı olarak belirir. Kadın ve Korkuluk oyununda diğer oyunlarından farklı olarak mitleri tekrar yazma stratejisini kullanmamış olsa da Korkuluk karakteri ile oyuna hem gotik bir hava vermeyi bașarır hem de kendi yazım stiline uygun yeni karakterler yaratır. Kadın ve Korkuluk oyunu Carr'ın ölüm temasını merkeze alarak bireyin ölüm gerçeği ile karşılaștığı anda yaşamın bir anlamının olmadığını fark ederek yaşayacağı o ölüm anını ve ölüm korkusunu izleyiciye hissettirmektedir. Carr ölüm gerçeğini bir gölge karakteri üzerinden izleyiciye yansıtmayı amaçlar. Geçmișiyle ölüm döșeğinde hesaplaşmaya çalıșan ve bunun acısını kendisinden çıkaran yaşlı bir kadının ölüm anı Carr tarafından oyundaki Kadın ve Korkuluk karakterleri ile ölüm gerçeğinin simgeleştirilmeye çalıșılmasıdır. Bu çalışma, Carl Gustav Jung'un kișilik kuramı bağlamında ele aldığı ve bilinçaltımızdaki imgelerin oluşturduğu kişiliğin karanlık yönünü oluşturan gölge arketipini, Carr tarafından yaratılan Korkuluk karakteriyle ele almaktır.

Anahtar sözcükler: Arketipler, gölge, Jung, doppelganger, Kadın ve Korkuluk.

Akademik disiplinler/alanlar: Edebiyat, sahne sanatları, psikoloji.

- Corresponding author: Cüneyt Özata, Yabancı Diller Bölümü, Fen Edebiyat Fakültesi, Ordu Üniversitesi.

- $\quad$ Address: Ordu Üniversitesi, Fen Edebiyat Fakültesi, Yabancı Diller Bölümü, İngiliz Dili ve Edebiyatı A.D., Ordu, Türkiye.

- e-mail: cuneyt.ozata@hotmail.com

- ORCID: 0000-0002-9179-9537

- $\quad$ Available online: 21.12 .2020

- doi: $10.17484 /$ yedi.756262 


\section{Introduction}

Regarded as perhaps the most prominent of all writers of contemporary Irish theatre, which has a deeprooted literary tradition from past to present, and growing up in the state of Offaly Marina Carr was born in Dublin on November 17,1964, and is one of the daughters of a family with six children, and her mother is a primary school teacher. Carr met theatre at a young age through her father who is a playwright and novelist. Completing University College Dublin with degrees in English and Philosophy, Carr was also an active participant of the school's drama community during her university education, and her first play Ullaloo, which she wrote in college, was performed at the Dublin theatre festival in 1989. Being very interested in theatre, Carr began studying her MA in Samuel Beckett, one of the most significant playwrights of Absurd theatre. Her play, Low in the Dark, written in 1990, was given its first production at the Dublin Art Projects Centre. Written in 1991, The Deer's Surrender was staged at Lane theatre in Dublin. The Mai, as the first of Midlands Triology, attracts considerable attention from the audience and critics alike. It was first performed in 1994 and received the Best New Irish Play award at the Dublin theatre festival. This play was followed in the series by Portia Coughlan, first published in 1996, and By the Bog of Cats... (1998), the latter of which received the best new play award. Ariel, first staged in 2002, is a single act play, and it was followed by Meat and Salt. Her Woman and Scarecrow (2006) premiered at the Royal Court (Sierz, 2010, p. 38).

Similar to the plays set in accordance with the village and rural life of Ireland, which is always apparent in the Irish theatre tradition and provide the fundamental material for the plays, Carr's plays seem to take place in the twilight belt in the Irish countryside. As Doyle states, "Carr's plays grow out of that 'great, new, modern Ireland' but, in many ways, they reproduce, half a century on, the insular sensibilities of The Field" (Doyle, 2010, p. 498). Although the plays are generally located in watery places in a gloomy atmosphere, Carr examines domestic life, family and woman that has a struggle for existence in a patriarchal system for centuries rather than rural life in Woman and Scarecrow. "In contemporary Irish theatre the work of Marina Carr pushes the boundaries of theatrical representation to the limit before crossing them to reveal a passionate enactment of exile and alienation" (Richards, 2004, p. 150). It is an "exile from self-expression, from self-determination" (Richards, 2004, p. 150).

Carr is the silent cry of women who cannot escape the male supremacy in traditional Irish life, are locked in the houses called families, are exposed to violence and incest, cannot form a unique and powerful identity, and are looking for an escape through 'suicide' (Haughton, 2013, p. 73). Melissa Sihra expresses the matter of whether women can progress within the narrow boundaries drawn by men and form an identity in a family environment with this statement:

In Carr's plays the family is a site of contestation, disunity and violation where the tenacious exploration of womanhood and issues of gender and sexuality crucially resist the monological nationalist, masculinist, colonial, and postcolonial issues of identity and history that have tended to dominate Irish dramatic narratives over the last century. (Sihra, 2005, p. 234)

The rural life of Ireland is generally at the boundary of life that is extremely Catholic and guided by church drive. Although within this framework of life, Carr's plays are considered to be based on family and family life, the main protagonist of her plays is the type of woman who is a wife, a lover, or a mother seeking to escape from this dilemma through suicide, where she is not valued by her husband in marriage. Family life depicted as it is in Woman and Scarecrow is not a picture of happy families living in the Irish countryside; on the contrary, the metaphor of the house is a photograph of a solemn life, which is not visible from the outside, but unwelcome by women: "In the very male-centered drama of Ireland, Carr takes the risk of dramatizing the women's experience in a rural setting divorced from Irish nationalism and national identity definitions" (Sayın, 2008, p. 76).

On the other hand, the environment in the opening scene of the play depicted with the image of an elderly woman lying on the bed, sent from the hospital to her home due to her deadly illness from which she had no hope to recover appears actually just a dull and chilly room of the house. The room is treated as a metaphor in this play by Carr, and with this room metaphor, Carr seems to be broadcasting live from the grave like a host recounting the moment of death of an old woman. Woman and Scarecrow, in a sense, can be said to be a ritual engagement of the spectators to the funeral of a woman coordinated by Marina Carr.

Also, in a conversation with Sihra, Carr describes death as:

The fact that we are dying probably is the only significant thing for all of us. And how we live, and how we die. I think that is so important - how one dies. I love 
biography because I love reading about how people die. I think it says everything about how they have lived - it is extraordinary. I love the idea of the tragedy of man and woman. It is the only significant thing about us - that we are going.

(Sihra, 2003, p. 56)

In addition to using Greek Myths to attract the audience's interest and make the play interesting, Carr reflects such binary oppositions as real vs imagination and destruction vs creation in her plays. In addition, Carr does not directly name her characters in Woman and Scarecrow. Four characters are given life in this two-act play, the plot of which is formed through Woman's uncanny state on the threshold between life and death on her death bed while having a debate with her so-called 'inner voice' -Scarecrow- and her womanizer Husband's occasional visits. Auntie Ah is another character visiting Woman to mostly warn and to blame her, sometimes to pray with her and to say, 'I've warned you before.' Despite the casual visits by Husband and Auntie Ah, Scarecrow seems to be the only character accompanying Woman throughout the whole play. Scarecrow as a hazy figure answers the questions that Woman essentially asks herself, sometimes reminding her of what happened in the past and helping her face herself, making Scarecrow act as the inner voice of Woman and having her think about her unfulfilled life by judging and reassuring her at the same time. The play consists of a dialogue between Woman and a Scarecrow figure that Woman has probably established in her mind. It represents the talk that she is having with her inner voice.

The Scarecrow figure, then, can be explored in the play as the doppelgänger or the shadow of Woman and it seems probable to analyse the role of this figure as the conscience of the main character, Woman. Considering the standing of this doubled Woman character in establishing the plot of the play, it would be essential to discuss the ways the doppelgänger figure has been defined in diverse ways by various theorists and how this concept appears in literature before examining the character of Scarecrow as the second self of Woman intertwined with the death theme.

Živković defines the doppelgänger "As an imagined figure, a soul, a shadow, a ghost or a mirror reflection that exists in a dependent relation to the original, the double pursues the subject as his second self and makes him feel as himself and the other at the same time" (Živković, 2000, p. 122). The connection between the two selves is very crucial in that they both are the same and different at the same time, most of the time existing as two separate sides in the same person's identity. The doppelgänger figure can also be described as an 'evil twin'. Another definition of the second self by Živković is as follows: "The double is defined as evil precisely because of its difference and a possible disturbance to the familiar and the known" (Živković, 2000 , p. 124). In other words, according to Živković, the second self can make the first one suffer as an enemy. This shadowy figure, which may appear having many different roles and definitions, is the copy of the first self, sometimes very similar to it and sometimes very different from it, but always having some kind of connection with it meeting on a common ground with each and every definition mentioned so far.

Nevertheless, the double as seen from the Jungian perspective is different. Jungian archetypes delve into the psyche of the person and show the inherent qualities, such as persona and shadow. In light of the shadow archetype as the double-figure, Živković claims that:

Unlike Freud, Jung sees the Self as complexio oppositorum, where good and evil are simply complementary opposites, each a necessary condition for the existence of the other. In his doctrine of the shadow he defines the double as neither good nor bad, but as 'a replica of one's own unknown face.' It acquires a demonic aspect only because one side of the personality is repressed and subordinated to a faultless and absolute good. (Živković, 2000, p. 125)

The idea of the collective unconscious can be broadly defined as the part of one's mind which existed within one's relatives and genetic relationship and continues to do so with the help of cultures and genes. The acceptance as a child that one's mother is figure of strong attachment or that somehow there is a divine being who controls and oversees everything happening on Earth can be said to be the result of this collective unconscious. Though these images and thoughts are hard to accept at first, the later stages of human consciousness respond to them not as strangers but something familiar. The reason, for example, why babies hold their mothers in great respect is that the image of a mother is inherently found within their psyches (Burger, 1997, p. 102). All these images are, in fact, passed down from generation to generation, froming what Jung labelled as archetypes. These archetypes are mainly developed throughout an individual's experiences in life. God-image, darkness, parents, and death can be claimed to exemplify some of these archetypes, making them almost limitless in scope and number. However, four of them are of utmost importance as seen in his writings as "there are as many archetypes as there are typical situations 
in life" (Jung, 2014a, p. 48). Perhaps the most known and studied are persona, anima/animus, self and shadow, which form the basis of his idea.

The shadow archetype consists of one's repressed feelings and qualities that one hides from others. One's shadow is the dark side within them that the individual conceals from the eyes of everyone involved in one's life. It "contains the unconscious part of ourselves that is essentially negative, or to continue the metaphor, the dark side of our personalities" (Burger, 1997, p. 102). It is Jung's belief that every person has a shadowy personality however unwilling one may be to accept it as such. What the individual does in the cases of unacceptance of such a figure is to project it onto others. Projection is the identification process of one's qualities with an outside object by way of alienation. People who do not want to encounter the shadow side of their personality think that they get rid of it by projecting their shadows outside. This projection of one's shadow mainly has negative impacts on one's relationship within a certain social context, from which people can save themselves by accepting the existence of their shadow. Only then can one find the self. In Jung's words, "The shadow is that hidden, repressed, for the most part inferior and guilt-laden personality whose ultimate ramifications reach back into the realm of our animal ancestors and so comprise the whole historical aspect of the unconscious." (cited in Diamond, 1996, p. 96). In another sense, shadow is a part within a person which is mainly primordial and can hardly be escaped. To further the explanation, shadow does not always seem like a dark or abysmal side of human consciousness, but it can "...also displays a number of good qualities, such as normal instincts, appropriate reactions realistic insights, creative impulses, etc." (cited in Diamond, 1996, p. 96).

Drawing on the confrontation of the self with the alternative one, Jung says:

This confrontation is the first test of courage on the inner way, a test sufficient to frighten off most people, for the meeting with ourselves belongs to the more unpleasant things that can be avoided so long as we can project everything negative into the environment. But if we are able to see our own shadow and can bear knowing about it, then a small part of the problem has already been solved: we have at least brought up the personal unconscious. The shadow is a living part of the personality and therefore wants to live with it in some form. It cannot be argued out of existence or rationalized into harmlessness. This problem is exceedingly difficult, because it not only challenges the whole man, but reminds him at the same time of his helplessness and ineffectuality. (Jung, 2014a, p. 20)

The way an individual accepts the existence of her, or his shadow is of utmost importance in correcting the flaws the individual might possess or, sometimes, stopping dwelling on the past, which is achieved through the occurrence of mutual company:

We carry our past with us, to wit, the primitive and inferior man with his desires and emotions, and it is only with an enormous effort that we can detach ourselves from this burden. If it comes to a neurosis, we invariably have to deal with a considerably intensified shadow. And if such a person wants to be cured it is necessary to find a way in which his conscious personality and his shadow can live together. (Jung, 2014a, p.3)

The shadow figure usually acts like a 'neighbour', upon which one can shed 'projections' of one's unconscious being (Jung, 1967, p. 297). Moreover, the shadow allows a person to judge their self in a more effective way as he or she becomes able to view the self from two various sides and stand in the middle (Jung, 2014b, p. 463). It goes without saying that Jung does ask us to embrace our shadowy sides in the hopes of bettering ourselves as well as others in the process:

It is a frightening thought that man also has a shadow side to him, consisting not just of little weaknesses- and foibles, but of a positively demonic dynamism. The individual seldom knows anything of this; to him, as an individual, it is incredible that he should ever in any circumstances go beyond himself. But let these harmless creatures form a mass, and there emerges a raging monster; and each individual is only one tiny cell in the monster's body, so that for better or worse he must accompany it on its bloody rampages and even assist it to the utmost. Having a dark suspicion of these grim possibilities, man turns a blind eye to the shadow-side of human nature. Blindly he strives against the salutary dogma of original sin, which is yet so prodigiously true. Yes, he even hesitates to admit the conflict of which he is so painfully aware. (Jung, 2014a, p.30) 
This does not, of course, mean that one's shadow can always be a good one that helps better the person. In such circumstances as neurosis, it is possible to view one's double as a threatening figure. As such, the notion of what is real or not may be said to have blurry lines after such an experience by the conscious of the unconscious:

\begin{abstract}
Whenever contents of the collective unconscious become activated, they have a disturbing effect on the conscious mind, and contusion ensues. If the activation is due to the collapse of the individual's hopes and expectations, there is a danger that the collective unconscious may take the place of reality. This state would be pathological. If, on the other hand, the activation is the result of psychological processes in the unconscious of the people, the individual may feel threatened or at any rate disoriented, but the resultant state is not pathological, at least so far as the individual is concerned. Nevertheless, the mental state of the people as a whole might well be compared to a psychosis. (Jung \& Hull, 1997, p.122)
\end{abstract}

Thus, the shadow may take forms of different beings in the mind which might then take the place of the real for the individual though others would not be aware of it. One is bound to be either 'a maniac or a savage beast', and as people, it is in our nature to put blame 'on external circumstances' than to accept our wrong doings; this, then, is when the shadow figure comes in and allows our feelings and emotions to detonate as if, as Jung puts it analogically, 'living on the edge of a volcano' (Jung, 1960, p. 16).

\title{
2. Discussion
}

In line with this, the shadow side of the original self is bound to seek for a way out of the so-called trap that it is in, where it has stayed for far too long to endure being kept at bay for any longer, which, in turn, allows one's second self to uncover certain openings in the way to existence and act as if it were an entirely autonomous presence of its own. It may thus be argued that one's ignorance of one's second being triggers a form of susceptibility in the individual.

The double characters in the play have various functions contributing to the plot together with certain aims having a unique role just like the other characters. As Keppler categorizes the Second Self figure, the doubles may appear in many different forms such as a Savior, a Tempter, a Pursuer, and as a Vision of Horror in distinct contexts (Keppler, 1972, p. 55). The role and the form of Woman's shadow is essential particularly for the main character of the play. These two interlinked characters (Woman and Scarecrow) complementing each other "... are eventually brought together as part of a symbolic (or psychological) process of self-reckoning through dying" (Curtin, 2019, p. 201). Actually, this doubled Woman character is "a mixture of exhausted resignation and fighting spirit" (Sierz, 2010, p. 48). The different roles that are given to the second self-figure by Carr with different purposes unite around the same centre of becoming the repetition of the first self as an inner voice of Woman throughout the play.

This repetition of the first self sometimes leads to a kind of self-discovery for the main self. Adrian Curtin says: "Likewise, it tracks with Carr's general thematic interest in death, which figures in many of her plays and is frequently coupled with self-discovery" (Curtin, 2019, p. 197). In Carr's Woman and Scarecrow, Woman is having a journey during which she discovers herself on her deathbed with the help of a second self-figure presented as Scarecrow. This self-discovery that the main character experiences through the end of her life helps her find her real inner self. Walter suggests that "the notion that dying provides the last opportunity for the person to become truly authentic, to acknowledge his or her real inner self" is a particularly modern, post-Freudian conception of personhood in which there is "a distinction between 'inner self' and 'outer expression'" (Walter, Walter and Walter, 1994, p. 44). So, with this Scarecrow figure the inner self of Woman is both revealed to the audience and to Woman herself. This dying woman is in a process of learning through the hallucinations she is experiencing throughout the whole play. So, this deathbed becomes a learning place not only for the character itself but also for the readers to some extent as they hear her inner voice through the Scarecrow figure.

Whether the double-figure functions as a punishing agent symbolizing conscience, or a figure that helps the protagonist achieve self-development and become a more complete person, it still completes the first self in one way or another. Along with this, the presentation technique of this double figure is also crucial to be explored, in terms of narration and how the usage of first- or third-person point of view contributes to the effect characterization has on the readers. The assumption is that first-person narrative would contribute to the ambiguity of the double figure's existence, while the third person narrative would contribute to the credibility of the double figure by making the reader sure of its presence. This ambiguity and blurred 
perception of Scarecrow created thanks to the writing style of Carr leads to several kinds of readings about the function of it in the play. "The fantastical characters may thus be understood as psychological projections - mechanisms by which Woman can conduct a self-reckoning before she dies (like Duffy's Everyman)" (Curtin, 2019, p. 198). The ambiguity that Marina Carr presents to the reader can justify the interpretation for the Scarecrow figure as a fantastic and supernatural figure to represent the inner voice of Woman eventually.

The woman character in Woman and Scarecrow, which "is set in a bedroom in the present, somewhere in the Irish Republic" (Curtin, 2019, p. 197) is presented in a miserable way on her deathbed. None of her achievements are mentioned or shown; instead, her body is old and controlled with no joy or happiness. "Females in Carr's plays are, accordingly, frequently depicted as stifled, dominated and often the victims of male violence" says Catherine Rees (2017, p. 57). The woman in this play is not a victim of male violence physically; however, she is obviously a victim of a dominant male figure. This dominance is not actually a patriarchal one suffocating and oppressing Woman; however, it is one that drags Woman into sorrow. The play explores death, pain and yearning for her past having a suffering female figure on the focus. "Carr offers a modern, sociological explanation of the psychological destruction of women" (Dedebaș, 2013, p. 259) says Dedebaş pointing to Woman's recognition of her own desperate situation in Act I when she says: "I'm being buried alive. I am my own ghost" (Carr, 2010, p. 43). Woman ends her life mourning and grieving for her unfulfilled life in the last scene of the play. In addition, this pain and suffering are doubled by the presence of the Scarecrow figure taking its part as the conscience of Woman presented in an allegorical way. Although Scarecrow is not directly and clearly a projection of the second self, it still can be explored as a double motif as the focus here is on the pursuit of Woman by the double. Scarecrow never leaves Woman alone and never lets her decide and think alone. Scarecrow is depicted as a blurry figure the presence of which is not clearly known for certain, which makes the reader think of it as a mysterious illusion of Woman. But still, it is mentioned in the character list as an independent and visible one, which makes it an actual figure having her own lines. The reader is left uncertain about if the other characters see or hear Scarecrow or not as a physical character; however, Woman insists on the presence of it. Up to this point, it has been a question whether it is a physical double or just an illusion interrupting Woman's last days on Earth. As a result, the reader is never convinced of the independent occurrence of this mysterious creature. However, it is obvious that Scarecrow enters Woman's thoughts, becomes her shadow, and controls her.

Although no physical resemblance is mentioned between Woman and Scarecrow, the thing that makes Scarecrow a double for Woman is that it never leaves her alone and plays a role as an inner voice knowing anything about her life and controlling her in her decisions. In addition, even though Scarecrow distracts her by reminding her of her unhappy past and criticizing her on her wrong decisions mostly about her husband, it is not a tyrant follower for Woman. It is an obtrusive and disruptive delusion for Woman from which she cannot escape. Even though she is mostly comfortable with it, it is a pursuing and torturing conscience. However, it still has an ambiguous position in Woman's life even if just as a hallucination that she creates in her mind. In spite of the fact that Scarecrow is a disturbing inner voice, it is somehow helping Woman to realize herself and complete her self journey. This doubled female character being the victim in the story waiting for her husband for ten years destructs herself under the influence of the pills she is taking as she cannot silence her inevitable inner voice- the so characterized Scarecrow throughout the play and suffers a lot from it. This inner voice haunts Woman and makes her feel deep sorrow by reminding her about the loneliness she has had dealing with children all alone without her husband accompanying her all those years. This kind of psychological destruction Woman experiences on her death bed contributes to her success of self-realization at the end of the play when Scarecrow uses her blood as an ink to write her story. "This juxtaposition of destruction and creation in Carr's plays serves the purpose of creating a new identity and finding a starting point that will help the silenced women reclaim their agency" (Dedebaș, 2013, p. 267). This victimized female figure in the play finds a way to form her own identity through her double, Scarecrow. "Her dying, then, enables her to speak for herself ultimately" (Dedebaş, 2013, p. 268). This final scene where Woman dies and her story is being written by Scarecrow actually can be read as evidence where the reality and fantasy are intertwined; nevertheless, it still contributes to Scarecrow being a powerful double-figure superseding Woman's inner voice.

The play begins with Scarecrow reminding Woman which path she has chosen in her life and telling her that this path is wrong, and she is lost. Woman saying, "I thought you were the navigator" (Carr, 2010, p. 5) reveals to the reader that Scarecrow is a figure that has been guiding her throughout her life as an inner voice and second self. At this point, it would not be wrong to take this inner voice -Scarecrow- as a shadow for Woman. Even when her flirtatious husband comes to visit and apologize to her on her deathbed, she asks Scarecrow what to do. She asks about her own decisions as if she is consulting her best friend, the most trustworthy friend she has created in her own mind, and she gets an answer from Scarecrow in sometimes 
an accusing and sometimes judgmental tone. This second self guides Woman with an attitude that shows that Scarecrow has intervened in every decision she has made in her life and judges her when she does not act on what it says. In addition, Scarecrow is not literally an illusion that she has created in her mind, it is an actual character that is mentioned in the play, which creates a kind of mysterious atmosphere.

In addition to Scarecrow's interventions to Woman's thoughts and feelings, for Campos, labelling the play as "Woman's death-bed lament to her alter-ego or subconscious, Scarecrow" (Campos, 2008, p. 48), Scarecrow is not such a strong figure influential in leading Woman's life. Scarecrow's interventions are for changing her life in a way to make her a much more powerful figure to take the control of her own life and spend it with pleasure. On the contrary, "Woman ignored and gave up Scarecrow-the symbol of her personal power, her feelings, and her identity" (Campos, 2008, p. 50). Further to that, she estranges her inner voice dispelling it to an inactive and shadowy state, which eventually drives her to an unfulfilled and unhappy life even if she cannot get rid of this illusion of Scarecrow even on her last breath. So, the play can be read as "a journey through inner landscapes of the self and soul to death and beyond" (Sihra, 2018, p. 189).

It is still obvious that Scarecrow has been with Woman as a follower and intruder even in the most private parts of her life, and this can be inferred from the lines she says: "It's wonderful to have such a critical spectator on all one's most intimate journeys" (Carr, 2010, p. 13). She does not even leave Scarecrow only as a spectator; on the contrary, she asks it to remind her of how she felt despite she herself is the one living through them all. "Pity I don't remember it then. Was I happy? Parading naked around the room?" (Carr, 2010, p. 13). This question that he asks to the Scarecrow is one of those questions that people ask themselves when they are alone with their own conscience. People continue to question whether they are happy or not and wait for their inner voice to respond and verify their feelings. Scarecrow answers these questions in Carr's play. It is the inner voice of Woman that reminds her what she experienced and how she felt in the past so much so that Woman asks Scarecrow about whether she herself is still alive or not: "Am I still breathing?" (Carr, 2010, p. 11) as Scarecrow is almost always aware of Woman's feelings and wishes: "But admit it, you've always loved the idea of dying" (Carr, 2010, p. 9). Sometimes, even while we do not know what we want, it is very likely that another character who knows it better than us is an inner voice. In the play, it is possible to catch many clues just like the examples mentioned above to make a deduction for the same outcome.

Despite being one of the characters in the play who speaks and physically takes place on the stage, Scarecrow, which we define as a shadow for Woman, can also be interpreted as an imagination of Woman. Carr says; "Scarecrow is an aspect of herself. It is a dialogue between self and soul" (Carr, 2007). It is an imaginary guide for her to converse with and to consult to when she is too weak and unconscious to talk with her husband and Auntie Ah. Together with this, it would not be wrong to evaluate this imaginary character as an evil twin that disturbs, provokes, and annoys her throughout the play, rather than being a secret friend who comforts and makes her feel good. The questions asked by Scarecrow are also worth paying attention to at this point. While asking why she married her womanizer husband knowing that he was not good for her, and asking if she still likes him or not, Scarecrow fights with Woman until she reveals what she really thinks and how she feels, and thus displays her fight with her conscience. Another scene that we can evaluate with a symbolic approach to the confrontation of Woman with herself is the moment when Woman asks for a mirror from Scarecrow.

Bring me the mirror please... To watch myself die. I want to see how I am. I always look in mirrors to find out what's happening to me. Please bring me the mirror. I want to see if I'm still here... Are they? Show? I can't see. (Carr, 2010, p. 12)

With these lines above, Woman is begging Scarecrow to help her face the reality about her own life. This confrontation through the mirror is also an inner fight that Woman has. Another scene that shows Scarecrow is a disturbing doppelgänger for Woman is the one where it says that her husband is not interested in the heart-breaking details of her life. This second self causes the woman to regret even on her last breath and die with an internal fight with her conscience, instead of helping her to end her unfulfilled life in peace.

Indeed, through this self-confrontation that Woman experiences thanks to Scarecrow, not only Woman but also “... we are informed of her faults and follies" (Haughton, 2013, p. 72). Moreover, Woman's confessions and her death -dying process- is what reveals Scarecrow's real mission in the play. This negotiation Woman has held with Scarecrow -her inner voice- about her experiences in life comforts her on her deathbed in addition to the disturbance that it gives to her. "To come to terms with her own death, she must first 
excavate reason and peace for her experiences in life, both as a gendered being and as a living, breathing, individual being" (Haughton, 2013, p. 73). To acknowledge her death, she pushes herself to go back over her roles in society and especially in her family. Reconsidering the most crucial stages of her life becomes a real struggle for her as she realizes how she has passed her life doing what the others and society expects from her. Woman groans: “Why didn't I have more sex when I could have?" (Carr, 2010, p. 32). She finds an answer to this question very quickly thanks to Scarecrow saying, "You were too busy hoovering" (Carr, 2010 , p. 32). At the end she gives in to Scarecrow and confesses her fault in hiding behind the household chores and 8 children that she has given birth.

The Woman hesitating about doing what Scarecrow says often allows this second self to lead her life by listening to this inner voice and even asking what decisions she should make and what she herself thinks. Woman supports this aforesaid claim with following lines, "Do I have a choice?" (Carr, 2010, p. 36) as an answer to Scarecrow's offer for her to take dictation from it when she wants to write a letter. However, there are also scenes where Woman still protests this Scarecrow figure and tries to establish authority over it. At the beginning of the play, Woman strives to show Scarecrow that the control is in her hands by threatening it to hold her breath saying, "Now you know who's boss" (Carr, 2010, p. 7). In so doing, she wants to suppress her inner voice. The fact that Scarecrow makes many of her decisions in the following scenes can be interpreted as a way for Woman to comfort and console herself regarding her initial effort to establish authority over Scarecrow.

In fact, these two separate characters, which form two different identities of a single self, complement each other, and cause the reader to think that Woman and Scarecrow are the same person in many parts of the play. Although they often appear as two different characters by creating a sense of uncertainty and ambiguity, the reader can read the implications that these two are the same character between the lines. The implication that each and every decision made affects both of them in the same way can be found first when Scarecrow says: "All my life I've been doing as you say and look where it's landed us" (Carr, 2010, p. 6). In the following scenes, Scarecrow says: "He loved you. More. He loved me... He saw me and he loved me. But you couldn't handle that, jealous surface bitch that you are" (Carr, 2010, p. 18-19). Here, it is more like we are reading a fight between two women about a man. Scarecrow saying "...you could be with him now. I could be with him now instead of this funeral parlour." (Carr, 2010, p. 19) confuses the reader one more time. It is as if two different characters play the same role at the same time. So much so that Scarecrow says: "I'll smoke for both of us" (Carr, 2010, p. 19) to Woman who wants to smoke. Another scene showing that these two characters represent the same person is when Woman and Scarecrow start saying the same things at the same time while Woman is speaking. They start talking like a one single person. Sayin, "And I thought it would be so for all of time apportioned to us here. And then you denied me. And how. For a very long time I thought I had done something" (Carr, 2010, p. 39).

The pronoun they use is 'us' in the first sentence and then continues as 'me'. This makes the reader think about the possibility of a single character speaking to herself right from the very beginning of the play. The fact that Scarecrow is only in dialogue with Woman at the beginning of the play can be evaluated as a proof showing that this character symbolizes the inner voice of Woman.

While suggesting that there are two separate selves that complement each other appearing sometimes as one and the same character in the play, it is also important to interpret Scarecrow's presence in the play compared to other characters. It is noteworthy at this point that the other two characters in the play do not see Scarecrow and that they do not have any dialogue with it. From this point of view, it would not be wrong to make a claim that this character is an illusion of Woman that she has created in her mind. In the first scene, when the woman speaks to her husband, she consults Scarecrow about her husband's question. It refuses to answer claiming she does not care about its thoughts in a reproachful manner. The woman asks if this sentence is memorized or not (to Scarecrow or/and her husband). However, there is uncertainty about whether she is asking this question to her husband or Scarecrow. Because either way, the dialogue is complete and there is no stage direction clearing this up. However, her husband answers the question and continues to speak.

HIM. Can you forgive me, my dear?

WOMAN. (To Scarecrow) Can I?

SCARECROW. Since when have you considered my opinion?

WOMAN. Your callous treatment of me. Did you rehearse that phrase?

HIM. Did I what? 
WOMAN. It was more than callous. Don't pretty it up for a deathbed (Carr, 2010, p. 16).

In fact, the presence of the inner voice as a third character intervening in the dialogue between Woman and her husband is evident. However, the dialogue continues as if no one intervenes. Based on the scene above, we can see that Him (her husband) cannot hear or see Scarecrow.

In the second act of the play, we get the clue that Scarecrow is invisible to Auntie Ah. While Woman asks her to save Scarecrow from the wardrobe, Auntie Ah does not pay attention to what Woman says, and they start praying, implying that Woman is hallucinating.

WOMAN. It's going to kill her.

AUNTIE AH. The state of the room. Swear there was a wrestling match here.

WOMAN. Get her! Get her! Help her! Scarecrow's still in the wardrobe.

AUNTIE AH. Ah, there's always someone in the wardrobe. Come on, we'll say a decade of the rosary.

WOMAN. (Calls.) Scarecrow, would a rosary help? (Carr, 2010, p. 28)

In this scene, we can take Scarecrow as a shadow for Woman accompanying her throughout the play, which she has created only in her mind acting as her inner voice. At the end of the play, Woman gives her last breath alone in the arms of Scarecrow. She is alone with his inner voice.

\section{Conclusion}

Based on the analysis above, it can be said that Scarecrow appears as a shadow and a second self which symbolizes the inner voice of Woman throughout the play. In addition, the dialogues between Woman and Scarecrow can be evaluated as Woman's fight with her own inner voice, conscience, and feelings. The fact that she is consulting Scarecrow even when she thinks about forgiving her husband contributes to the idea that this shadow figure is her inner voice. At the same time, evaluating this figure as a twin or a second self can leave the analysis incomplete. On the contrary, it can be said that bringing Woman face to face with herself, Scarecrow acts as an inner voice that disturbs, judges, and criticizes her. Although she accepts this confrontation in silence in many parts of the play, it can be easily read between the lines that she sometimes tries to get rid of it.

Carr's insistence on delving deep into the minds of women is also apparent. Both Woman and Scarecrow share important qualities even though they should be opposites. Woman's acceptance of Scarecrow as a part of her consciousness further illuminates Jung's ideas regarding the inescapable nature of the shadow. The projection of her inner self does not come at the cost of another human being, but in her inner self. Through this projection and acceptance of her shadowy figure, Woman manages to find her true self and reinvent an identity imposed on her for so very long. As a result, leaving the fact that the characters of Woman and Scarecrow act as two separate characters, it can be concluded that Scarecrow is a shadow as defined by Jung acting as the inner voice of Woman.

\section{References}

Burger, J. M. (1997). Personality. California: Brooks/Cole Pub. Co.

Campos, H. J. (2008). Marina Carr's hauntings: Liminality and the addictive society on and off the stage. (Doctoral dissertation, Brigham Young University, Provo). Retrieved from: https://scholarsarchive.byu.edu/etd/1451

Carr, M. (2007, Eylül 23). Playwrights in profile [Radio broadcast]. RTE Radio 1.

Carr, M. (2010). Woman and scarecrow. New York: Dramatists Play Service, Inc.

Curtin, A. (2019). Death in modern theatre: Stages of mortality. Manchester: Manchester University Press.

Dedebaş, E. (2013). Rewriting of tragedy and women's agency in Marina Carr's by the bog of cats..., Ariel, and woman and scarecrow. Women's Studies, 42(3), 248-270. 
Diamond, S. (1996). Anger, madness and the daimonic: The psychological genesis of violence, evil, and creativity (Foreword by Rollo May. A volume in the SUNY series in the Philosophy of Psychology). Albany: State University of New York Press.

Doyle, M. (2010). Slouching towards Raftery's hill: The devolving patriarch in Marina Carr's midlands plays. Modern Drama, 53(4), 495-515. Retrieved from: https://muse.jhu.edu/article/407725

Haughton, M. (2013). Woman's final confession: Too much hoovering and not enough sex. Marina Carr's woman and scarecrow. Mortality, 18(1), 72-93.

Jung, C. G. (1960). Psychology and religion. Connecticut: Yale University Press.

Jung, C. G. (1967). The philosophical tree. In Adler G. \& Hull R. (Eds.), Collected Works of C.G. Jung, Volume 13: Alchemical Studies (pp. 251-350). Princeton: Princeton University Press.

Jung, C. G. \& Hull, R. (1997). The psychological foundations of belief in spirits. In Psychology and the Occult: (From Vols. 1, 8, 18 Collected Works) (pp. 108-125). Princeton: Princeton University Press. Retrieved from: www.jstor.org/stable/j.ctv10crg6v

Jung, C. G. (2014a). The archetypes and the collective unconscious. London: Routledge.

Jung, C. G. (2014b). Two essays on analytical psychology. London: Routledge.

Keppler, C. F. (1972). The literature of the second self. Arizona: University of Arizona Press.

Rees, C. (2017). Adaptation and nation: Theatrical contexts for contemporary English and Irish drama. London: Springer.

Richards, S. (Ed.). (2004). The Cambridge companion to twentieth-century Irish drama. Cambridge: Cambridge University Press.

Sayın, G. (2008). Quest for the lost m/other: Medea re-constructed in Marina Carr's By the Bog of Cats... (1998). Cankaya University Journal of Arts and Sciences, 1(9), 75-87. Retrieved from https://dergipark.org.tr/tr/pub/cankujas/issue/4015/53020

Sierz, A. (2010). Marina Carr. In Martin M. and Peter P. S. (Eds.), The Methuen Drama Guide to Contemporary Irish Playwrights (pp. 37-56). London: Methuen.

Sihra, M. (2003). Reflections across water: New stages of performing Carr. In Leeney C. and McMullan A. (Eds), The Theatre of Marina Carr: Before Rules Was Made (pp. 92-113). Bray: Carysfort Press.

Sihra, M. (2005). 'Nature noble or ignoble': Woman, family, and home in the theatre of Marina Carr. Hungarian Journal of English and American Studies (HJEAS), 11(2), 133-147.

Sihra, M. (2018). Marina Carr: Pastures of the unknown. London: Springer.

Walter, J. A., Walter, T. \& Walter, H. E. (1994). The revival of death. Hove: Psychology Press.

Živković, M. (2000). The double as the 'unseen' of culture: Toward a definition of doppelgänger. Facta Universitatis-Linguistics and Literature, 2(7), 121-128. 